\title{
Health behaviors and their correlates among participants in the Continuing to Confront COPD International Patient Survey [Corrigendum]
}

Müllerová $\mathrm{H}$, Landis $\mathrm{SH}$, Aisanov Z, et al. Int J Chron Obstruct Pulmon Dis. 2016;11:881-890.

On page 882 , right column, second paragraph, the sentence "The primary hypotheses were addressed using the PAM$13,{ }^{2}$ and Morisky Medication Adherence Scale (MMAS)- $8 .{ }^{18}$ should have read "The primary hypotheses were addressed using the PAM-13, ${ }^{2}$ and Morisky Medication Adherence Scale (MMAS)-8. ${ }^{18,40,41}$

On page 882, right column, last paragraph, the sentence "Adherence is classified as low (score 1-5), medium (score 6-7), or high (score 8) according to the overall score." should read "Adherence is classified as low (score $<6$ ), medium (score 6 to $<8$ ), or high (score 8 ) according to the overall score."

On page 886 , Table 3, the copyright statement "Use of the CMMAS is protected by US copyright laws. Permission for use is required. A license agreement is available from: Donald E Morisky, ScD, ScM, MSPH, Professor, Department of Community Health Sciences, UCLA School of Public Health, 650 Charles E. Young Drive South, Los Angeles, CA $90095-$ 1772..$^{18,40,41 "}$ was not included in the Note section.

On page 882, right column, last paragraph, the sentence "Each question is given either a dichotomous or Likert scaletype response resulting in an overall score which ranges from 1 to 8, with higher scores indicating greater adherence." should have read "Each question is given either as a dichotomous or Likert scale-type response resulting in an overall score which ranges from 0 to 8 , with higher scores indicating greater adherence."

International Journal of COPD

\section{Publish your work in this journal}

The International Journal of COPD is an international, peer-reviewed journal of therapeutics and pharmacology focusing on concise rapid reporting of clinical studies and reviews in COPD. Special focus is given to the pathophysiological processes underlying the disease, intervention programs, patient focused education, and self management protocols.
On page 889, Acknowledgment section, the acknowledgment read "The survey was conducted by Abt SRBI, a global survey research firm. The authors would like to acknowledge editorial support in the form of draft outline manuscript development, assembling tables, collating author comments, and copyediting which was provided by Kate Hollingworth of Continuous Improvement Ltd. This editorial support was funded by GSK. This study was funded by GSK." However it should have read "The survey was conducted by Abt SRBI, a global survey research firm. The authors would like to acknowledge editorial support in the form of draft outline manuscript development, assembling tables, collating author comments, and copyediting which was provided by Kate Hollingworth of Continuous Improvement Ltd. This editorial support was funded by GSK. This study was funded by GSK. Use of the CMMAS is protected by US copyright laws. Permission for use is required. A license agreement is available from: Donald E Morisky, ScD, ScM, MSPH, Professor, Department of Community Health Sciences, UCLA School of Public Health, 650 Charles E Young Drive South, Los Angeles, CA 90095-1772."

On page 890 , References, these references were not included:

40. Krousel-Wood MA, Islam T, Webber LS, Re RS, Morisky DE, Muntner P. New Medication Adherence Scale Versus Pharmacy Fill Rates in Seniors With Hypertension. Am J Manag Care. 2009;15(1):59-66.

41. Morisky DE, DiMatteo MR. Improving the measurement of self-reported medication nonadherence: Final response. J Clin Epidemio. 2011;64:258-263.

\section{Dovepress}

This journal is indexed on PubMed Central, MedLine and CAS. The manuscript management system is completely online and includes a very quick and fair peer-review system, which is all easy to use. Visit $\mathrm{http} / / / \mathrm{www}$.dovepress.com/testimonials.php to read real quotes from published authors.

Submit your manuscript here: http://www.dovepress.com/international-journal-of-chronic-obstructive-pulmonary-disease-journal 